\title{
Short-range transcriptional repressors mediate both quenching and direct repression within complex loci in Drosophila
}

\author{
Susan Gray and Michael Levine \\ Department of Biology, Center for Molecular Genetics, University of California at San Diego, La Jolla, California \\ 92093-0347 USA
}

The early Drosophila embryo provides a unique system for the analysis of transcriptional repression since a broad spectrum of repressors are distributed in spatially distinct patterns. Krüppel (Kr) and snail (sna), two zinc finger repressors, are essential for segmentation and for the establishment of the mesoderm/neuroectoderm boundary, respectively. Both repressors were examined in the context of synthetic gene complexes containing modular promoters and divergently transcribed reporter genes. These studies indicate that $\mathrm{Kr}$ and sna function as short-range repressors, which can mediate either quenching or direct repression of the transcription complex, depending on the location of repressor sites. When located within an upstream enhancer, the repressor locally quenches nearby activators and permits other enhancers to interact with the transcription complex (enhancer autonomy). In contrast, when bound to promoter-proximal regions the repressor functions in a dominant fashion and blocks multiple enhancers. Local quenching and dominant repression require close linkage ( $<100 \mathrm{bp}$ ) of the repressor with either upstream activators or the transcription complex. These studies establish short-range repression as a flexible form of gene regulation and suggest that the key distinction among repressors is their range of action.

[Key Words: Drosophila embryo; transcriptional repression; zinc finger repressors; Krüppel; snail; gene regulation]

Received December 18, 1995; revised version accepted February 1, 1996.

Previous studies have demonstrated the importance of transcriptional repression in establishing cell type-specific patterns of gene expression. The yeast $\alpha 2$ homeo domain protein specifies the $\alpha$-cell phenotype by repressing a-specific genes (Keleher et al. 1992). In the Drosophila embryo, stripes of segmentation gene expression are established by repressors that define the borders of individual stripes (for review, see Pankratz and Jackle 1990; Small and Levine 1991). Repression is also essential for establishing the boundary between the presumptive mesoderm and neuroectoderm (Alberga et al. 1991; Kosman et al. 1991; Leptin 1991). In addition, repressors both define and maintain the expression limits of homeotic selector genes (Paro 1993; Busturia and Bienz 1993; Chan et al. 1994). Numerous examples of transcriptional repression have been observed in mammalian systems. For example, repression establishes the rhombomere-specific pattern of Hoxb-1 expression within the hindbrain region of the mouse embryo (Studer et al. 1994). Repression is also essential for B-cell specific expression of the immunoglobulin heavy-chain enhancer (Genetta et al. 1994) and the regulation of CD4 expression in different T-cell lineages (Sawada et al. 1994; Siu et al. 1994).
Several different modes of repression have been proposed, including competition, quenching, and direct repression of the transcription complex (for review, see Levine and Manley 1989; Johnson 1995). The yeast $\alpha 2$ homeo domain protein represents the most thoroughly characterized eukaryotic repressor. Occupancy of $\alpha 2$ operator sites depends on cooperative DNA-binding interactions with a general transcriptional activator, $\mathrm{Mcm} 1$ (Vershon and Johnson 1993). Once bound, $\alpha 2$ recruits the Tup1 repressor, which directly inhibits the transcription complex over distances of $200 \mathrm{bp}$ to $1 \mathrm{~kb}$ (Keleher et al. 1992; Herschbach et al. 1994; Cooper et al. 1994). It is unclear whether Tupl also works in a local fashion to inhibit (quench) the neighboring $\mathrm{Mcm} 1$ activator.

In vitro transcription experiments and transient transfection assays suggest that a number of mammalian repressors, including nuclear receptor proteins such as the glucocorticoid and thyroid hormone receptors, might directly repress the transcription complex (Stromstedt et al. 1991; Drouin et al. 1993; Fondell et al. 1993). However, in many instances repressor binding sites are contained within composite cis regulatory elements that map far $(>200 \mathrm{bp})$ from the transcription start site (Pearce and Yamamoto 1993). It is conceivable that such 
repressors mediate both local quenching of upstream activators and direct repression of the transcription complex. To address this issue we have analyzed the activities of two Drosophila zinc finger repressors, snail (sna; Boulay et al. 1987) and Krüppel (Kr; Gaul and Jackle 1987).

sna is directly activated by the maternal dorsal (dl) regulatory gradient (Ip et al. 1992a) and is expressed specifically in ventral regions where it defines the limits of the presumptive mesoderm (Ip et al. 1994). sna represses the expression of rhomboid (rho) in the mesoderm and thereby restricts its expression to lateral stripes in the presumptive neuroectoderm (Ip et al. 1992b). $K r$ is regulated by the bicoid (bcd) maternal gradient (Hoch et al. 1992); its expression is restricted to central regions of the embryo corresponding to the presumptive thorax and anterior abdomen (Gaul and Jackle 1987). Kr helps establish pair-rule stripes of gene expression, at least in part, by functioning as a repressor (Zuo et al. 1991; Licht et al. 1993; Sauer et al. 1995). For example, it represses the even-skipped (eve) stripe 2 enhancer and thereby defines the posterior stripe border (Stanojevic et al. 1991; Small et al. 1991, 1992).

Recent studies suggest that sna represses transcription through a short-range quenching mechanism /Gray et al. 1994). A 300-bp enhancer is responsible for regulating lateral stripes of rho expression in the early cmbryo. This enhancer contains high-affinity dl sites, as well as basichelix-loop-helix (bHLH) activator sites; these work synergistically to activate rho in both ventral and lateral regions (Ip et al. 1992b). The enhancer also contains four closely linked sna repressor sites that exclude expression from the ventral mesoderm. Two of these sites directly overlap activator sites (Ip et al. 1992b), suggesting that sna might function through a competition mechanism. However, modified rho enhancers were subsequently shown to direct essentially normal patterns of expression even when sna repressor sites were moved 50-75 bp away from the closest activators. These observations prompted the proposal that sna may work over short distances to quench nearby activators through local protein-protein interactions (Gray et al. 1994).

Here, we present evidence that $\mathrm{Kr}$ can also function through a short-range quenching mechanism, as suggested by previous tissue culture assays (Zuo et al. 1991). This observation challenges previous proposals that $\mathrm{Kr}$ defines the posterior border of eve stripe 2 through competition (Stanojevic et al. 1991; Small et al. 1991, 1992). Moreover, sna and $\mathrm{Kr}$ are shown to function in promoter-proximal regions of test promoters, presumably through a direct repression mechanism. The range of repression is similar for quenching and direct repression; that is, sna and $\mathrm{Kr}$ must bind near (within $100 \mathrm{bp}$ ) upstream activators or the transcription start site. The location of the repressor sites, within upstream enhancers or promoter-proximal regions, determines distinct patterns of gene expression. When located within an upstream enhancer, the repressor functions in a local fashion and permits other enhancers to make contact with the transcription complex (enhancer autonomy). In con- trast, the same repressor functions in a dominant fashion and blocks multiple enhancers, when located near the transcription start site. These results suggest that a common repressor can mediate both quenching and direct repression of the transcription complex and that short-range repression represents a flexible form of gene regulation.

\section{Results}

Efficient ventral repression of the rho neuroectoderm enhancer element (NEE) requires close proximity of sna and dl binding sites (Gray et al. 1994). sna was also found to inhibit the heterologous bcd activator when bound within the eve stripe 2 enhancer or a synthetic enhancer containing bcd and dl activator sites. These findings prompted the proposal that short-range repression should allow enhancers to function autonomously within complex, modular promoters (Gray et al. 1994). An example of a synthetic modular promoter is shown in Figure 1A. A nearly additive staining pattern (lateral and transverse stripes| is observed when a minimal 152-bp rho NEE is placed upstream of the 480 -bp eve stripe 2 enhancer. sna bound to the rho NEE represses $\mathrm{dl} / \mathrm{bHLH}$ activation in the presumptive mesoderm but does not interfere with ventral activation of the neighboring stripe 2 enhancer. The most closely linked sna and bcd sites are separated by $\sim 175 \mathrm{bp}$, beyond the range of efficient sna repression (see diagram below Fig. $1 \mathrm{~A}$ and summary in Fig. 1B).

The $\mathrm{Kr}$ repressor also appears to function locally, within the limits of the eve stripe 2 enhancer (Fig. 1B). However, there is a slight attenuation of the rho lateral stripes in central regions containing peak levels of $\mathrm{Kr}$ protein (arrows, Fig. 1A). Subsequent studies (see Fig. 5) suggest that the $\mathrm{Kr}$ site at the $3^{\prime}$ end of the stripe 2 enhancer, located just 45 bp from the transcription start site, mediates direct repression of the transcription complex. This repression is relatively weak, as the bcd activator and $\mathrm{Kr}$ repressor compete for overlapping binding sites (Small et al. 1991, 1992; see below).

\section{Kr appears to mediate direct repression of the transcription complex}

$\mathrm{Kr}$ can repress a defective 700-bp rho NEE that lacks all four sna repressor sites (NEE $\Delta$ sna). As shown previously (Ip et al. 1992b), removal of the sna site causes a loss of ventral repression, so that there is equal expression in both ventral and lateral regions (Fig. 2A). In these experiments, the NEE $\Delta$ sna was placed between two divergently transcribed promoters, a leftward white reporter gene and a rightward lac $Z$ gene. The expression of either gene can be assayed independently by in situ hybridization using digoxigenin-labeled white or lacZ antisense RNA probes (Tautz and Pfeifle 1989; Cai and Levine 1995).

$\mathrm{Kr}$-binding sites positioned $50 \mathrm{bp}$ upstream and $55 \mathrm{bp}$ downstream of the nearest $\mathrm{dl}$ activator sites result in an almost complete loss of staining in central regions where 


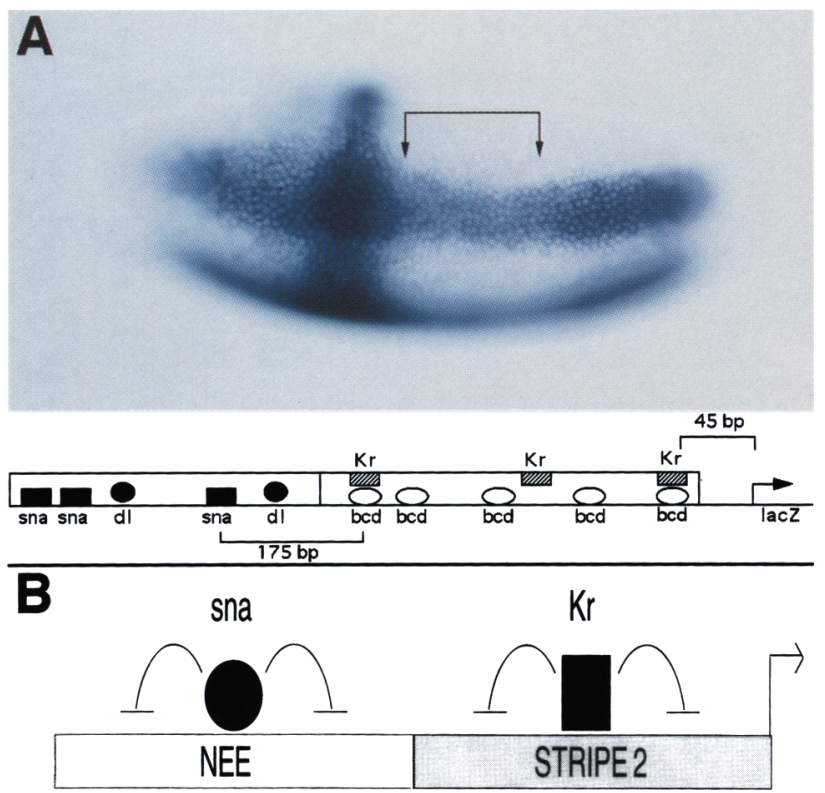

Figure 1. Enhancer autonomy in a modular promoter. The transgenic embryo is oriented with anterior to the left and dorsal up. It contains a fusion promoter with a minimal, 152-bp rho NEE placed upstream of the 480-bp eve stripe 2 enhancer (see summary diagram below the embryo). The expression pattern was visualized after hybridization with a digoxigenin-labeled $l a c Z$ antisense RNA probe. $(A)$ Embryo at the midpoint of nuclear cleavage cycle 14 . The staining pattern consists of rho lateral stripes and the transverse eve stripe. The stripe 2 enhancer contains five bcd activator sites and three $\mathrm{Kr}$ repressor sites, whereas the rho NEE contains two dl activator sites and three sna repressor sites. The most closely linked rho NEE repressor site and stripe 2 activator are separated by $175 \mathrm{bp} .(B)$ Summary of short-range repression and enhancer autonomy. The staining pattern obtained with the fusion promoter is additive, as repressors bound to one enhancer do not affect the neighboring enhancer. According to this diagram, the sna repressor functions in a local fashion to inhibit, or quench, nearby activators in the rho NEE. Activators in the neighboring stripe 2 enhancer map beyond the range of sna repression $1 \sim 50-100$ bp). Similarly, stripe 2 repressors, such as $\mathrm{Kr}$, do not interfere with the expression of the NEE.

there are high concentrations of $\mathrm{Kr}$ protein (Fig. 2A). The simplest explanation for this observation is that $\mathrm{Kr}$ locally quenches or inhibits nearby $\mathrm{dl}$ activators. This is supported by the observation that white is also repressed by $\mathrm{Kr}$ (Fig. 2B), even though the nearest repressor site maps $>550 \mathrm{bp}$ from the white initiation site (see diagram below Fig. 2A). Previous tissue culture assays are also consistent with the notion that $\mathrm{Kr}$ functions via quenching (Zuo et al. 1991).

Further evidence for short-range quenching was obtained by moving the $\mathrm{Kr}$ sites away from the $\mathrm{dl}$ activators. When positioned $\sim 150 \mathrm{bp}$ from $\mathrm{dl}$, $\mathrm{Kr}$ no longer represses white (Fig. 2D). This result is consistent with the notion that $\mathrm{Kr}$ must map within $\sim 100$ bp of upstream activators to inhibit expression, similar to the situation shown previously for sna (Gray et al. 1994).
However, we were surprised that this arrangement of $\mathrm{Kr}$ sites resulted in substantial repression of lacZ (Fig. 2C). The simplest explanation is that the proximal $\mathrm{Kr}$ site, located within $75 \mathrm{bp}$ of the lac $Z$ transcription start site, mediates direct repression of the transcription complex (see below). A number of additional experiments were done to determine whether $\mathrm{Kr}$ and sna can mediate both local quenching of upstream activators and direct repression of the transcription complex.

\section{sna can repress the transcription complex}

Our previous analysis of sna repression did not include a critical test for direct repression (Gray et al. 1994). sna sites located $\sim 50 \mathrm{bp}$ from $\mathrm{dl}$ activators restore ventral repression to an otherwise defective NEE $\Delta$ sna (Fig. 3A). This arrangement of sna sites results in efficient repression of both the rightward $l a c Z$ gene (Fig. 3A) and the leftward white gene (Fig. 3B). Repression is probably caused by local quenching of $\mathrm{dl}$ activators, as moving the sna sites another $100 \mathrm{bp}$ results in a near loss of snamediated repression (Gray et al. 1994). Moreover, sna represses white expression even though the closest sna site maps $550 \mathrm{bp}$ from the white initiator (Fig. 3B).

To determine whether sna can directly repress the transcription complex, two sna-binding sites were placed $\sim 50$ bp upstream of the $1 a c Z$ transcription start site. This results in efficient repression of the lac $Z$ pattern in ventral regions (Fig. $3 \mathrm{C}$ ). In contrast, white is depressed completely in ventral regions (Fig. $3 \mathrm{D}$ ), suggesting that sna does not interfere locally with $\mathrm{dl}$ but, instead, represses the $l a c Z$ promoter (the sna sites map $215 \mathrm{bp}$ from the nearest $\mathrm{dl}$ activator site in the NEE $\Delta$ sna).

Further evidence that sna can mediate direct repression was obtained by placing the NEE $\Delta$ sna $3^{\prime}$ of lac $Z$ (Fig. 4). The insertion of two sna sites $\sim 50 \mathrm{bp}$ upstream of the lacZ start site restores an essentially normal pattern (Fig. 4A). Repression is almost certainly caused by direct repression of the transcription complex, as the nearest NEE $\Delta$ sna activators now map $>4.5 \mathrm{~kb}$ from sna. Moving the sna sites another $75 \mathrm{bp}$ upstream of $l a c Z$ abolishes repression (Fig. 4B). These results suggest that sna can repress the transcription complex only over short distances, similar to the range observed for snamediated quenching of upstream activators.

\section{Dominant repression of multiple enhancers}

As discussed earlier, short-range repressors bound to one enhancer do not interfere with neighboring enhancers in a modular promoter (e.g., Fig. 1A). The next series of experiments examined how the activity of multiple enhancers might be affected by the placement of sna and $\mathrm{Kr}$ repressor sites near the transcription start site.

Previous studies identified a 260-bp enhancer (PE) from the twist (twi) promoter region that directs expression in the ventral-most 12-14 cells in response to peak concentrations of the $\mathrm{dl}$ regulatory gradient (Jiang et al. 1991; Pan et al. 1991; Thisse et al. 1991). Two tandem 


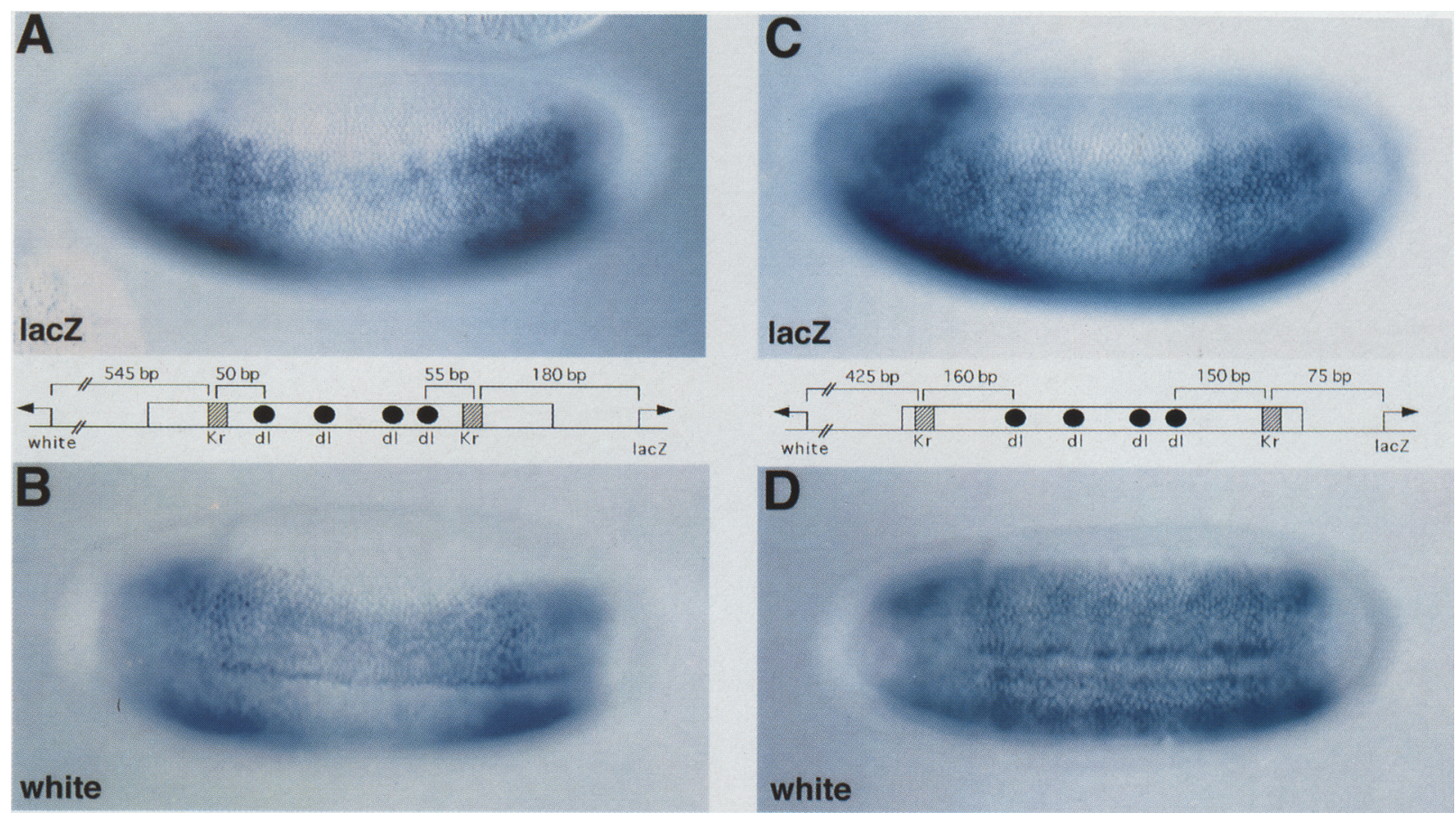

Figure 2. Kr can mediate short-range quenching of heterologous activators. Transgenic embryos are oriented as described in Fig. 1. Modified rho NEE sequences were inserted between two divergently transcribed reporter genes, white and lacZ, which can be visualized separately following in situ hybridization. These 700-bp rho NEEs lack native sna repressor sites (NEE $\Delta$ sna and contain synthetic Kr sites. (A) lacZ staining pattern of a precellular embryo containing the NEE $\Delta$ sna enhancer with Kr-binding sites located $\sim 50$ bp from dl-activator sites. Efficient repression is observed in central regions where there are high concentrations of Kr protein. The $\mathrm{Kr}$ sites map far from the white and lac $Z$ transcription start sites 1550 and $180 \mathrm{bp}$, respectively; see summary diagram below the embryo). (B) Gastrulating embryo containing the same fusion gene as in $A$, except that the white reporter gene is visualized. Efficient repression is observed in central regions. (C) lacZ staining pattern of a precellular embryo containing the NEE $\Delta$ sna with more distantly linked $\mathrm{Kr}$ repressor sites. These sites map $\sim 150 \mathrm{bp}$ from the nearest dl activator sites. Repression is nearly as efficient as that observed with more closely linked $\mathrm{Kr}$ sites (cf. A). (D) Gastrulating embryo containing the same fusion gene as in $C$ except that white expression is visualized. No repression is observed in central regions.

copies of this enhancer (2XPE) direct a somewhat more robust staining pattern than a single copy (Jiang and Levine 1993). A fusion promoter containing 2XPE placed upstream of the rho NEE directs an additive staining pattern, which consists of $r$ ho lateral stripes and a band of expression within the presumptive mesoderm (Fig. $5 \mathrm{~A}_{;}$arrow indicates the gap between the expression patterns directed by the two enhancers). A single Kr-binding site placed between the two enhancers, $>150$ bp from activators in either the 2XPE or rho NEE, has no discernible effect on the pattern (Fig. 5A). In contrast, both enhancers are repressed when the same $\mathrm{Kr}$ site is placed $\sim 75$ bp from the transcription start site (Fig. 5B). The rho NEE is attenuated in central regions, whereas 2XPE expression is nearly abolished.

sna was also tested for its ability to repress multiple enhancers when placed near the transcription start site. Figure 6A shows the staining pattern obtained with a fusion promoter containing the 480-bp eve stripe 2 enhancer placed upstream of a 500-bp stripe 3 enhancer. The two enhancers are separated by a 160-bp neutral spacer sequence from the native eve promoter region (Small et al. 1993). An additive staining pattern is observed, although stripe 2 expression is slightly weaker than stripe 3 staining (Fig. 6A). A variable head stripe results from cryptic regulatory sequences within the P-transformation vector (Jiang et al. 1991; Small et al. 1992). In addition, stripe 7 expression is mediated by regulatory sequences located primarily in the stripe 3 enhancer (Small et al. 1993, 1996). A cluster of four snarepressor sites has no effect on the ventral expression of either stripe 2 or stripe 3 when located in the spacer region. These map far (>150 bp) from the closest activators in either enhancer.

Stripe 2 is repressed in ventral regions when several sna sites are inserted within the stripe 2 enhancer (Fig. 6B). These sna sites map $\sim 30-40$ bp from critical bcd sites within the modified enhancer. Stripe 3 is unaffected, as the stripe 3 enhancer is located beyond the range of sna repression. The insertion of sna repressor sites just upstream of the $1 a c Z$ initiation site results in the ventral repression of both stripes (Fig. 6C). The stripe 2 pattern is somewhat more efficiently repressed than stripe 3 ; the stripe 2 enhancer may be inherently weaker than the stripe 3 enhancer (see Cai and Levine 1995). Nonetheless, these results suggest that sna can function as a dominant repressor to block multiple enhancers when bound near the transcription complex. 


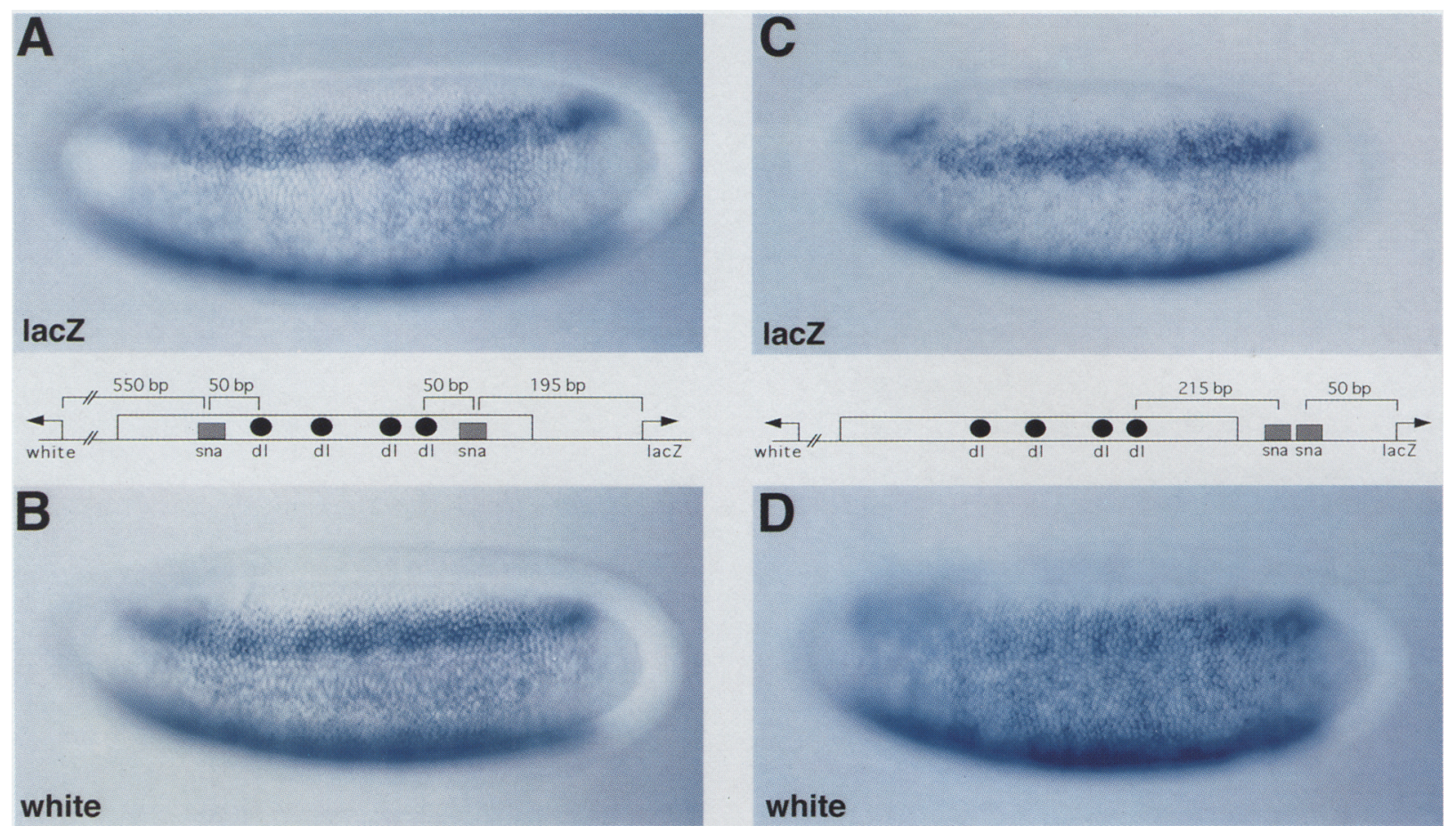

Figure 3. The sna repressor can silence the transcription complex. Transgenic embryos are oriented as described previously. They contain the 700-bp NEE $\Delta$ sna enhancer between divergently transcribed white and lac $Z$ reporter genes. $(A)$ lac $Z$ staining pattern in a precellular embryo with synthetic sna sites placed $\sim 50$ bp from dl activator sites (see diagram beneath the embryo). Efficient repression is observed in ventral regions where there are high concentrations of sna protein. $(B)$ Gastrulating embryo expressing the same fusion gene as $A$ except that white expression is monitored. Repression is observed in the presumptive mesoderm. (C) lac $Z$ staining pattern in a precellular embryo obtained with two sna sites placed $\sim 50$ bp upstream of the lac $Z$ transcription start site. These mediate efficient repression in the presumptive mesoderm. $(D)$ Gastrulating embryo expressing the same fusion gene as $C$ except that white expression is monitored. The sna sites located near lac $Z$ fail to repress white expression. Consequently, the staining pattern is derepressed in ventral regions.

\section{The sna repression domain can be uncoupled from DNA binding}

Previous studies have established that transcriptional activators possess distinct DNA-binding domains and activation domains (e.g., Chi et al. 1995). Repressors have not been characterized to the same extent, although recent tissue culture assays have identified discrete repression domains (Han and Manley 1993a,b; Gerwin et al. 1994; Licht et al. 1994). To determine whether the nonDNA-binding domain of sna is sufficient for repression in vivo, we analyzed the activities of a sna-Gal4 fusion protein in transgenic embryos.

A 200-bp rho NEE was modified extensively to make it responsive to the fusion protein (see Materials and methods). The modified NEE contains three dl, three twi, and three Gal4 upstream activating sequence (UAS) binding sites (see diagram below Fig. 7A) and directs strong expression in ventral and ventrolateral regions, encompassing $\sim 20-22$ cells (Fig. 7A).

The sna-Gal4 fusion protein consists of the non-DNAbinding domain of sna fused to the DNA-binding domain of the yeast activator Gal4. sna is composed of 390amino acid residues; the carboxy-terminal sequences lo- cated between amino acids 245 and 390 contain five zinc fingers that mediate DNA binding (Boulay et al. 1987; Ip et al. 1992b; Mauhin et al. 1993). sna coding sequences for amino acids 1-244 were placed upstream of the Gal4 amino acid 2-93 coding region. The fusion gene was placed under the control of a chimeric promoter containing the 2XPE twi enhancer attached to a $1.6-\mathrm{kb}$ sequence from the sna promoter region. As shown previously, this twi-sna chimeric promoter directs expression in the ventral-most 14-16 cells (Ip et al. 1994). The modified NEE was introduced into transgenic embryos expressing the sna-Gal4 fusion gene (Fig. 7B). The fusion protein mediates efficient repression in the ventral-most 14-16 cells, thereby converting the wide band of ventrolateral staining into two narrow stripes (cf. Fig. 7B and 7A).

The repression mediated by the sna-Gal 4 fusion protein is probably caused by short-range inhibition of nearby $\mathrm{dl}$ activators, rather than direct repression of the transcription complex. The proximal-most Gal4 site is located $>100$ bp from the $l a c Z$ transcription start site. A competition mechanism of repression is also unlikely, as Gal4 fusion proteins that activate gene expression do not repress the modified NEE. For example, the modified NEE is activated in anterior regions of transgenic em- 


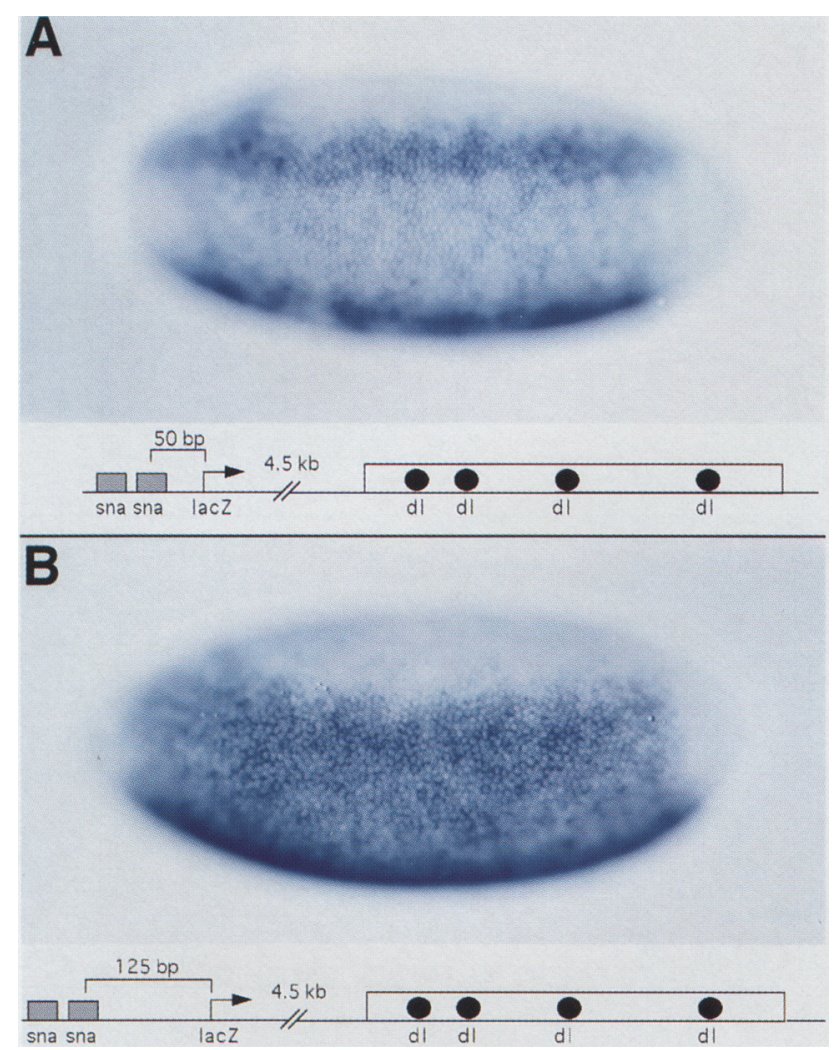

Figure 4. sna can silence a tho NEE located far from the transcription start site. Precellular, transgenic embryos are oriented as described previously. Both embryos contain a 700-bp rho NEE $\Delta$ sna downstream of the lacZ gene. (A) lacZ staining pattern obtained when two sna sites are placed $\sim 50$ bp from the transcription start site (see diagram beneath the embryo). Efficient repression is observed in the presumptive mesoderm. (B) Same as $A$ except that the sna sites were moved another $75 \mathrm{bp}$ from the lacZ start site. Little or no repression is observed, so that the staining pattern is derepressed completely in ventral regions. Different transgenic lines containing the fusion gene in $A$ exhibit somewhat variable staining patterns. The staining pattern in $A$ represents efficient ventral repression; other lines show slightly derepressed patterns (data not shown).

bryos containing an anteroposterior gradient of a bcdGal4 fusion protein (Simpson-Brose et al. 1994; data not shown).

\section{Discussion}

We have shown that short-range repression represents a flexible form of gene regulation. Binding of repressor to remote locations in the promoter region results in local inhibition, or quenching, of upstream activators. Other enhancers contained in the promoter are not influenced by the repressor and can interact freely with the transcription complex. In contrast, the binding of repressor to promoter-proximal regions results in the dominant repression of the promoter, so that multiple enhancers are blocked. This flexibility contrasts with long-range repressors (summarized in Fig. 8), which can block mul- tiple enhancers over distances of several kilobases regardless of location within a gene complex (Huang et al. 1993; Jiang et al. 1993; Kirov et al. 1993; Lehming et al. 1994). We propose that the most crucial distinction among repressors is their range of action.

\section{Short-range vs. long-range repression}

Previous studies have identified several apparently distinct modes of repression, including competition, quenching, and direct repression of the transcription complex (for review, see Levine and Manley 1989; Johnson 1995|. Evidence for competition stems from the organization of enhancers and promoter elements active in the early embryo. For example, four of the six repres-

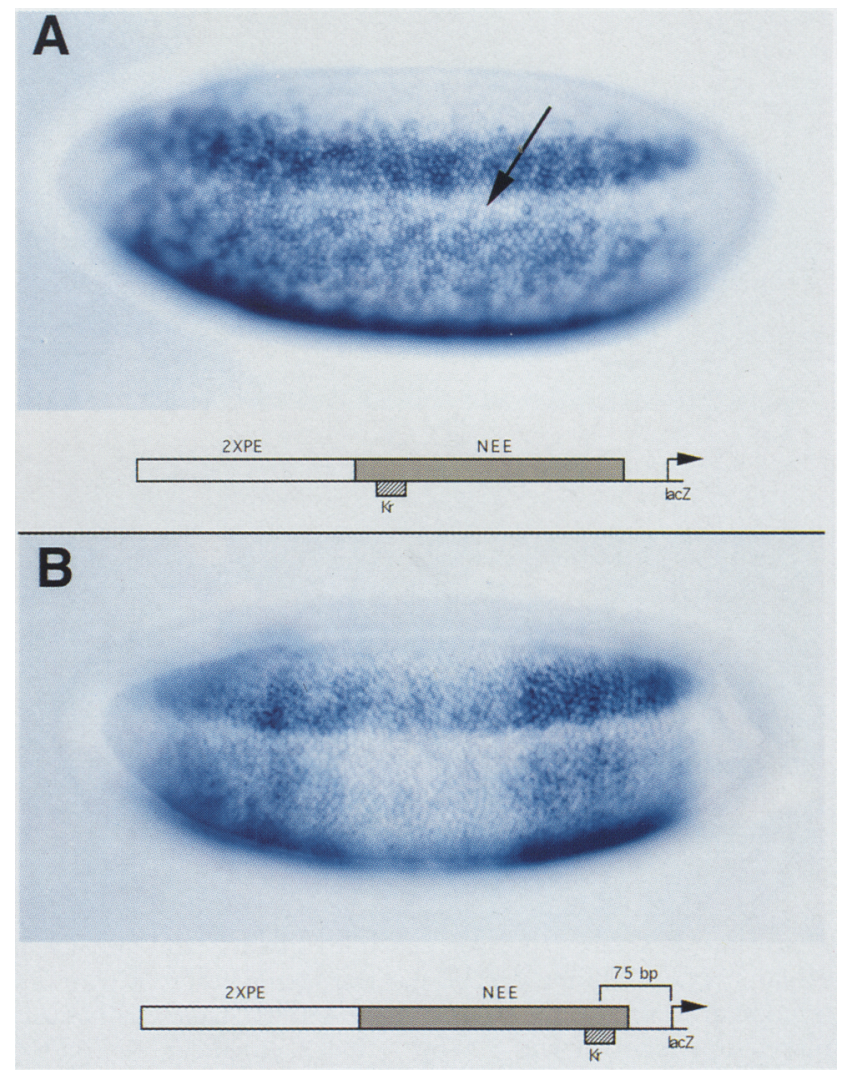

Figure 5. The $\mathrm{Kr}$ repressor can silence multiple enhancers. Precellular transgenic embryos are oriented as in Figs. 1-4. They express a synthetic modular promoter containing the 2XPE mesoderm-specific enhancer placed upstream of the rho NEE. $(A)$ $I a c Z$ staining pattern obtained with the fusion gene containing a single Kr-binding site located near the $5^{\prime}$ end of the 700-bp rho NEE (see diagram beneath the embryo). Neither enhancer is repressed, in that uniform staining is observed along the anteroposterior axis in both the presumptive mesoderm and neuroectoderm. The arrow shows the gap between the 2XPE and NEE expression domains. $(B)$ Same as $A$ except that the $\mathrm{Kr}$-binding site was placed $75 \mathrm{bp}$ upstream of the $l a c Z$ transcription start site. Both enhancers are repressed; mesoderm staining is nearly abolished in central regions containing high concentrations of $\mathrm{Kr}$ (2XPE enhancer), whereas the NEE lateral stripes are attenuated in the same domain. 


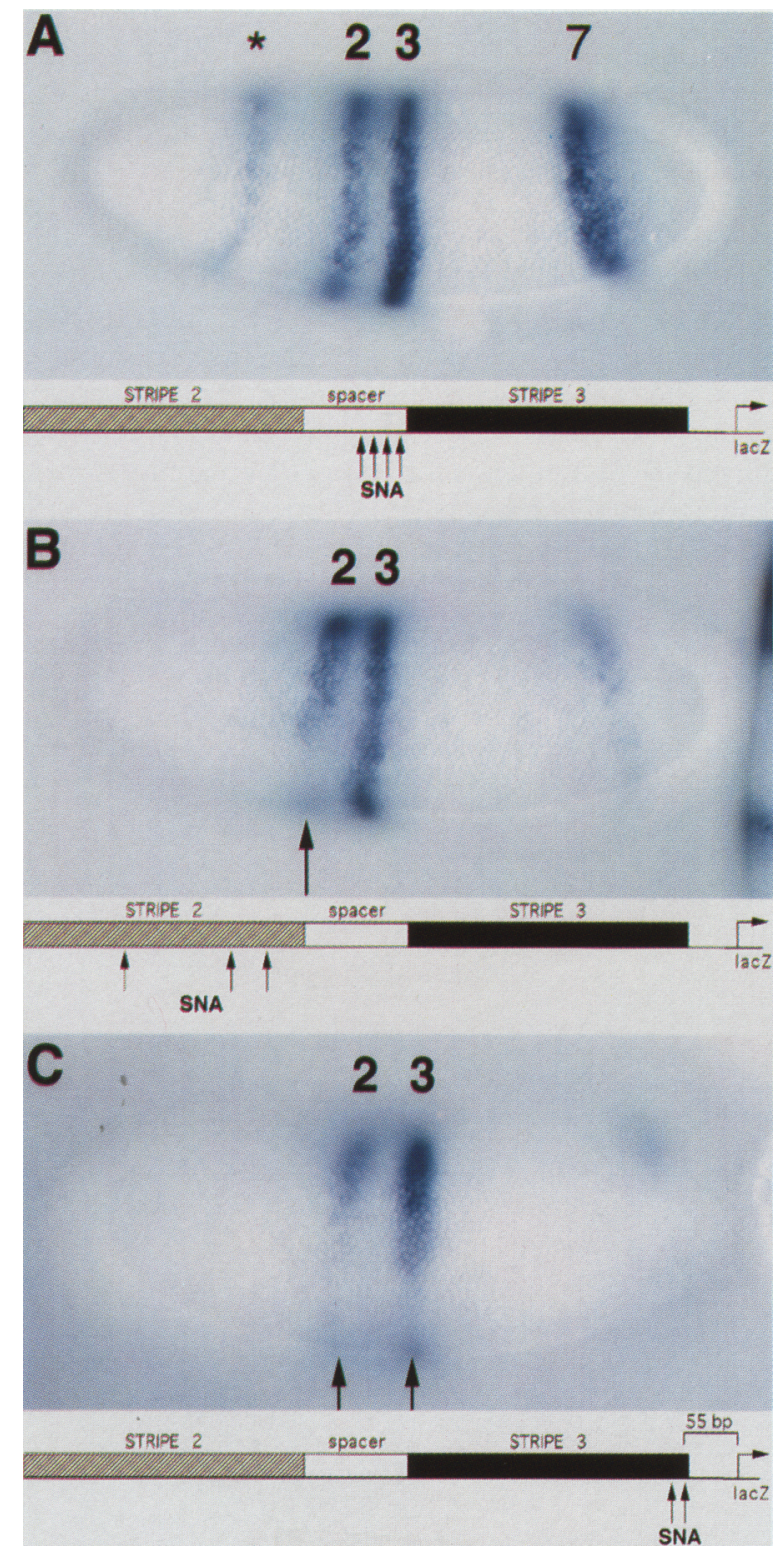

Figure 6. The sna repressor can both quench and silence a modular eve promoter. Precellular transgenic embryos contain a modular promoter consisting of the 480 -bp stripe 2 enhancer placed upstream of the 500-bp stripe 3 enhancer. A 160 -bp spacer sequence separates the two enhancers. $(A)$ lac $Z$ staining pattern obtained with the fusion promoter containing four sna repressor sites inserted in the spacer sequence (see diagram beneath the embryo). These sna sites map far from activators in both enhancers (>150 bp). Consequently, neither enhancer is repressed, and both stripes are expressed uniformly in dorsal and ventral regions. Note that stripe 7 expression depends on regulatory sequences located in both enhancers, primarily the stripe 3 enhancer. In addition, the anterior head stripe (asterisk) is attributable to cryptic regulatory sequences in the P-transformation vector. $(B)$ Same as $A$ except that three sna repressor sites were inserted within the stripe 2 enhancer. This results in the ventral repression of stripe 2 (arrow). The neighboring stripe 3 enhancer is unaffected. $(C)$ Same as $A$ and $B$ except that two sna sites were placed 55 bp from the lac $Z$ transcription start site. Both stripes 2 and 3 are repressed in ventral regions (arrows), suggesting that sna functions as a dominant silencer when bound near the initiation site.
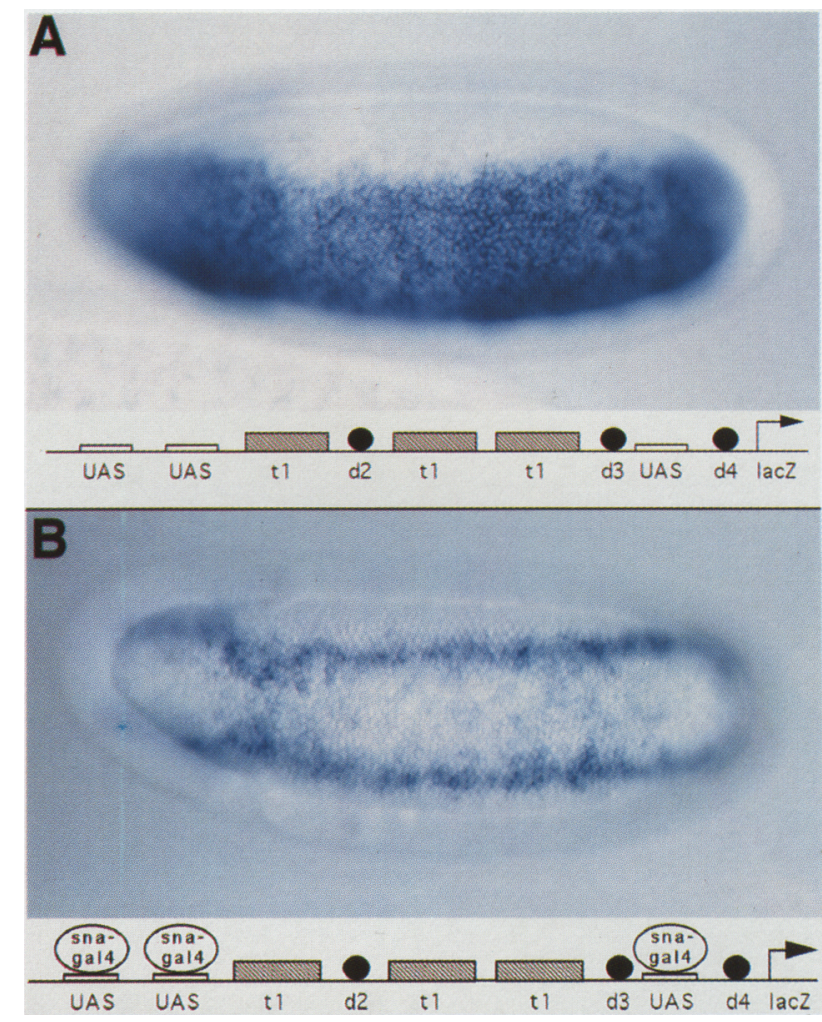

Figure 7. sna contains a discrete repression domain. Ventrolateral views of transgenic embryos expressing a modified rho NEE that lacks sna repressor sites and contains Gal4 recognition sequences (UAS; see summary diagrams beneath the embryos). (A) lacZ staining pattern obtained with the modified NEE in a normal embryo. A sharp staining pattern is observed in the ventral $20-22$ cells, which encompasses the presumptive mesoderm and mesectoderm. $(B)$ Same as $A$ except that the modified NEE was crossed into an embryo that expresses a snaGal4 fusion protein in the ventral-most $14-16$ cells. The NEE is repressed in regions containing the fusion protein.

sor sites in the eve stripe 2 enhancer overlap an activator site directly (Small et al. 1991, 1992). In particular, the bcd activator and $\mathrm{Kr}$ repressor recognize related binding sites (they share $7 / 10$ matches), suggesting that $\mathrm{Kr}$ defines the posterior stripe 2 border via competitive binding to DNA (Driever et al. 1989; Stanojevic et al. 1989; Treisman and Desplan 1989). However, we have presented evidence that $\mathrm{Kr}$ need not function in this manner. It can repress the heterologous rho NEE even when completely uncoupled from dl activator sites. These results are consistent with our previous analysis of sna and raise the possibility that competition and quenching may not represent fundamentally different modes of repression.

The yeast $\alpha 2 /$ Tupl complex appears to function via direct repression of the transcription complex (Herschbach et al. 1994). Repression is observed over distances of several hundred base pairs, and genetic studies suggest that the Tup1 repressor interacts with one or more SRBs (suppressor of RNA polymerase $\underline{B}$ ) in the RNA polymerase II (Pol II) holoenzyme complex (Hershbach et al. 1994; Barberis et al. 1995; Liao et al. 1995). It is unclear 

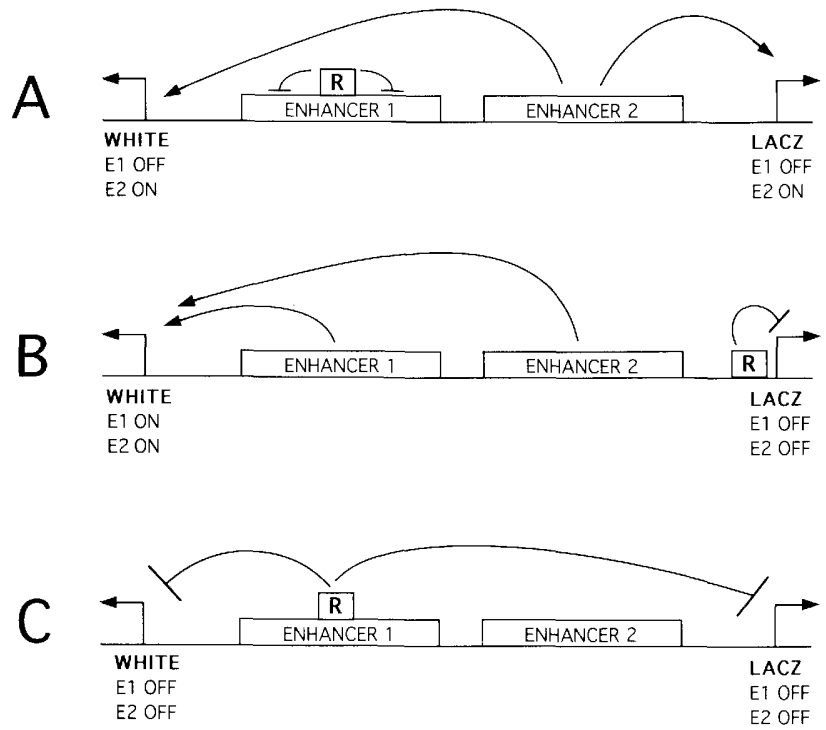

Figure 8. Short-range repression is a flexible form of gene regulation. The diagram depicts a gene complex containing two enhancers placed between two divergently transcribed genes, white and lacZ. (A) Binding of a short-range repressor to enhancer 1 . This enhancer is blocked from interacting with both the white and lacZ promoters (El off). However, the neighboring enhancer 2 is unaffected and activates both genes. In this configuration, the repressor permits enhancer autonomy (E2 is unaffected), but not promoter autonomy in that both genes are influenced by the repressor. $(B)$ Binding of a short-range repressor to promoter-proximal regions of the $1 a c Z$ gene. Both enhancers are blocked from interacting with $l a c Z$, so there is no enhancer autonomy. However, only lac $Z$ is repressed; white is unaffected, indicating that the two promoters are autonomous in their response to repressor. (C) Binding of a long-range silencer. In this case, the repressor acts over long distances to silence both white and lacZ. Both enhancers are blocked from interacting with both promoters. In principle, the silencer would exert the same effect on the gene complex regardless of location.

whether the $\alpha 2$-Tupl complex can also quench the neighboring $\mathrm{Mcm} 1$ activator or whether Tupl must be linked closely to activators to contact the transcription complex.

Direct repression has been implicated in both Drosophila and mammalian tissue culture assays. eve has been shown to silence transcription, possibly through direct interactions with the TATA-binding protein (TBP) (Han and Manley 1993a; Um et al. 1995). A similar mechanism might apply to engrailed (Han and Manley 1993b), although there is also evidence that it can quench upstream activators when bound at a distance from the transcription start site (Jaynes and O'Farrell 1991). In vitro transcription assays suggest that the unliganded form of the thyroid hormone receptor might block transcription, over short distances, by directly contacting TBP or TFIIB (Fondell et al. 1993). Finally, other members of the nuclear receptor family, such as glucucortcoid receptor (GR), can work as repressors when bound $>200$ bp from the transcription start site (Pearce and Ya- mamoto 1993/ and in promoter-proximal regions (Drouin et al. 1993). Thus, previous studies on repressors raise a number of basic issues. Do they quench, directly repress the transcription complex, and work over short or long distances?

Our analyses of transcriptional repression in the early embryo suggest that there may be two basic forms of repression: short-range and long-range. We have analyzed the activities of six different repressors that are localized in precellular embryos: sna, $\mathrm{Kr}, \mathrm{kni}$, giant (gt), dl, and hairy (Gray et al. 1994; Paroush et al. 1994; Arnosti et al. 1996; Arnosti et al., in prep.). Four of the six embryos, sna, $\mathrm{Kr}$, kni, and gt, appear to function over short distances, $<100 \mathrm{bp}$, to either quench neighboring activators within a target enhancer or directly repress the transcription complex (this study; Arnosti et al., in prep.). In contrast, both $\mathrm{dl}$ (and associated corepressors) and hairy appear to work over long distances $(\geqslant 1 \mathrm{~kb})$ to silence the transcription complex (Ip et al. 1991; Jiang et al. 1993; Kirov et al. 1993; Lehming et al. 1994). For example, $\mathrm{dl} /$ corepressors can repress the ventral expression of the eve stripe 2 enhancer over a distance of $\sim 5 \mathrm{~kb}$ (H. Cai and M. Levine, unpubl.). The hairy repressor can function in a dominant fashion and block multiple enhancers when bound $\sim 1 \mathrm{~kb}$ upstream of the transcription start site (S. Barolo and M. Levine, unpubl.).

\section{Mechanisms of short-range repression}

Several different mechanisms of repression can be envisioned. The simplest view is that the short-range repressor directly inhibits upstream activators through protcin-protein interactions. Perhaps sna and $\mathrm{Kr}$ repression domains block activator-promoter interactions. This direct mechanism of quenching may be compromised by the demonstration that both sna and $\mathrm{Kr}$ can silence the transcription complex when bound to promoter-proximal regions. However, it is conceivable that the repressors interact with upstream activators as they loop to the transcription complex. Alternatively, the repressors may recognize common motifs present in both upstream activators and the transcription complex (for review, see Goodrich and Tiian 1994).

Another potential mechanism involves the recruitment of one or more corepressors. As discussed above, the yeast $\alpha 2$ repressor recruits Tupl, which in turn inhibits the transcription complex (Hershbach et al. 1994). Moreover, hairy recruits groucho, which is related to Tup1 by virtue of WD40 repeats (Paroush et al. 1994). Perhaps hairy represses transcription through a grouchopromoter interaction similar to the situation described for $\alpha 2$-Tup1. Recent studies suggest that the Tupl repression complex is quite large, $>1$ million daltons, and contains multiple Tupl and Ssn6 subunits (A.D. Johnson, pers. comm.). Short-range repressors, such as $\mathrm{Kr}$ and sna, might recruit smaller repression complexes that function only over short distances.

Tissue culture assays and in vitro binding experiments suggest that $\mathrm{Kr}$ may repress transcription by interacting with the TFIIE- $\beta$ subunit of the transcription complex 
(Sauer et al. 1995). Our results do not rule out such a mechanism; however, we note that the earlier study also suggests that $\mathrm{Kr}$ activates transcription through interactions with TFIIB. A model was presented whereby $\mathrm{Kr}$ monomers activate transcription, whereas dimers mediate repression. However, we have shown that a single Kr-binding site causes both the rho NEE and twi 2XPE enhancers to be repressed continuously in response to the $\mathrm{Kr}$ protein gradient in central regions of the embryo (e.g., Fig. 2). Activation is not observed at the margins of the pattern where there are diminishing levels of $\mathrm{Kr}$ protein.

\section{Short-range repression in complex loci}

The flexibility of short-range repression is particularly evident for complex genetic loci (summarized in Fig. 8). In the present study a complex locus was created by placing a modular promoter between two divergently transcribed reporter genes, white and $l a c Z$. When either sna or $\mathrm{Kr}$ binds to a given enhancer (enhancer 1; see Fig. 8A), this enhancer is barred from interacting with both white and $l a c Z$. However, the neighboring enhancer 2 is free to interact with both genes. In this case, local repression permits enhancers to function autonomously. In contrast, when sna or $\mathrm{Kr}$ repressor sites are placed near the lacZ transcription start site, both enhancer 1 and enhancer 2 are blocked (Fig. 8B). Despite this dominant repression of $l a c Z$, both enhancers are unimpeded from interacting with the white gene. Thus, in this case, the short-range repressor permits promoter autonomy within a gene complex. This flexibility, enhancer autonomy or promoter autonomy, contrasts with the binding of long-range repressors within the complex, whereby both enhancers would be blocked on both promoters (Fig. 8C).

This form of repression might help explain localized patterns of homeotic gene expression within the Bithorax complex (BX-C). Repressors encoded by the gap genes hunchback $(h b), K r$, and knirps (kni), have been shown to play a critical role in establishing the anterior boundaries of BX-C gene expression (Zhang et al. 1991; Qian et al. 1991; Busturia and Bienz 1993). For example, $K r$ binds within the $i a b 2$ enhancer, which is located downstream of the abdominal-A (abd-A) gene (Shimell et al. $1994) . \mathrm{Kr}$ is required for keeping $a b d-A$ off, at least initially, in parasegment (PS) 6. It does not influence the expression of the neighboring Ultrabithorax $(U b x)$ gene, which is expressed in PS6, possibly because of the shortrange nature of $\mathrm{Kr}$ repression.

\section{Materials and methods}

\section{Plasmid constructions}

The synthetic fusion promoter containing the 152-bp rho NEE and 480-bp eve stripe 2 enhancer (Fig. 1A) has been described previously (Gray et al. 1994). The 700-bp rho NEE (Ip et al. 1992b; Gray et al. 1994) was inserted into the lacZ 3' polylinker of the C4PLZ transformation vector (Wharton et al. 1993). sna sites were created in the $5^{\prime}$ polylinker sequence by inserting a synthetic 35-bp sequence, containing two sna sites /CAGCAAGGTG) separated by a 10-bp spacer, into either the SphI or the KpnI site. The spacer sequence separates the sna s2 and s3 sites in the native rho promoter (Ip et al. 1992b). The 2XPE twi enhancer was inserted between the EcoRI and $K p n I$ sites of the C4PLZ vector; the 700-bp rho NEE (containing a synthetic $\mathrm{Kr}$ site) was cloned into the unique BamHI site. The eve stripe 2/stripe 3 fusion promoters (Fig. 6) were described previously (Small et al. 1993). Four sna sites were placed in the spacer between stripes 2 and 3 (Fig. 6A) by inserting two tandem copies of the 35-bp sequence, described above, into a synthetic SphI site located $150 \mathrm{bp} 3^{\prime}$ of the proximal bcd site in the stripe 2 enhancer. Two sna sites were placed $55 \mathrm{bp} 5^{\prime}$ of the lac $Z$ transcription start (Fig. 6C) by inserting one copy of the 35-bp sequence into a synthetic SphI site located at the $3^{\prime}$ end of the 500-bp stripe 3 enhancer. The sna sites in the stripe 2 enhancer (Fig. 6B) were created by site-directed mutagenesis (see below).

To construct the sna-Gal4 fusion sequence, an XhoI-XbaI fragment from the 2XPE twi-lacZ fusion gene (Jiang and Levine 1993) containing twi promoter sequences from -180 bp to $+160 \mathrm{bp}$ and the $l a c Z$ coding region was replaced by a truncated l.6-kb sna promoter (Ip et al. 1992a), driving the sna cDNA through codon 244 fused to the 5 ' end of the coding region for Gal4 amino acids 2-93. A synthetic NotI site creates three alanine codons between sna amino acid 244 and Gal4 amino acid 2.

The UAS reporter (Fig. 7; modified from the 200-bp rho NEE described in Gray et al. 1994) was synthesized from a series of oligonucleotides and subcloned into the unique NotI and BamHI sites of the C4PLZ vector. Binding site identities were confirmed by sequence analysis. The $\mathrm{dl} 2,3$, and 4 sites and the twi tl $\mathrm{E}$ box were unchanged. The twi $\mathrm{t} 2 \mathrm{E}$ box/sna $\mathrm{s} 4$ site and the E box/sna $s 3$ site were changed to the twi t 1 binding sequence (CATATG). The sna s2 site was replaced by a 15-bp dimeric Gal4-binding site (GGAGGACAGTCCTCC). Additional Gal4-binding sites were created at the 5 ' end of the modified NEE, and between the $\mathrm{d} 3$ and $\mathrm{d} 4$ activator sites. Gal4binding sites are located (relative to the putative rho transcription start) as follows: -1735 to $-1749 \mathrm{bp},-1842$ to $-1856 \mathrm{bp}$, and -1865 to $-1879 \mathrm{bp}$.

\section{$P$ element-mediated germ-line transformation} and whole-mount in situ hybridization

P-element transposons containing various lacZ/white reporter genes were introduced into the Drosophila germ line using standard methods (Spradling and Rubin 1982). Multiple independent transformed lines were examined for each fusion gene. Reporter gene expression was visualized by whole-mount in situ hybridization using digoxigenin-UTP-labeled lac $Z$ or white antisense RNA probes (Tautz and Pfeifle 1989; Jiang et al. 1991).

\section{Site-directed mutagenesis}

The pBluescript SK + plasmid and CJ236 strain of Escherichia coli were used to prepare uracil-containing single-stranded DNA templates. Mutagenesis was performed by annealing the templates with various mutagenic oligonucleotides. The in vitro-synthesized double-stranded DNA was transformed into the DH5 $\alpha$ strain of E. coli. The identities of the mutagenized templates were confirmed by sequence analysis.

Synthetic $\mathrm{Kr}$ sites (AAAACGGGTTAAGC) were created at the following positions in the rho NEE (all numbers refer to distance from the putative rho transcription start site): -2010 to $-2023 \mathrm{bp},-1639$ to $-1652 \mathrm{bp},-2129$ to $-2142 \mathrm{bp}$, and -1533 to -1546 bp. Synthetic sna sites (CAGCAAGGTG) 
were created in the rho NEE at -2012 to -2021 bp and -1649 to $-1658 \mathrm{bp}$.

Synthetic sna sites were created in the eve stripe 2 enhancer at -1153 to $-1162 \mathrm{bp},-1235$ to $-1244 \mathrm{bp}$, and -1386 to -1395 bp relative to the eve transcription start site.

Defective NEEs lacking native sna-binding sites were described by Ip et al. (1992b).

\section{Acknowledgments}

We thank Keith Maggert and Bob Zeller for help with computer imaging programs, and Liezelle de la Peña for technical assistance. We also thank Bill McGinnis and David Arnosti for critically reading the manuscript. This work was funded by grants from the National Institutes of Health (NIH) (GM34431 and GM46638).

The publication costs of this article were defrayed in part by payment of page charges. This article must therefore be hereby marked "advertisement" in accordance with 18 USC section 1734 solely to indicate this fact.

\section{References}

Alberga, A., J.L. Boulay, E. Kempe, C. Dennefeld, and M. Haenlin. 1991. The snail gene required for mesoderm formation in Drosophila is expressed dynamically in derivatives of all three germ layers. Development 111: 983-992.

Arnosti, D.N., S. Barolo, M. Levine, and S. Small. 1996. The eve stripe 2 enhancer employs multiple modes of transcriptional synergy. Development 122: 205-214.

Barberis, A., J. Pearlberg, N. Simkovich, S. Farrell, P. Reinagel, C. Bamdad, G. Sigal, and M. Ptashne. 1995. Contact with a component of the polymerase II holoenzyme suffices for gene activation. Cell 81: 359-368.

Boulay, J.L., C. Dennefeld, and A. Alberga. 1987. The Drosophila developmental gene snail encodes a protein with nucleic acid binding fingers. Nature 330: 395-398.

Busturia, A. and M. Bienz. 1993. Silencers in abdominal-B, a homeotic Drosophila gene. EMBO J. 12: 1415-1425.

Cai, H. and M. Levine. 1995. Modulation of enhancer-promoter interactions by insulators in the Drosophila embryo. Nature 376: 533-536.

Chan, C.S., L. Rastelli, and V. Pirrotta. 1994. A Polycomb response element in the $U b x$ gene that determines an epigenetically inherited state of repression. EMBO /. 13: 25532564.

Chi, T., P. Lieberman, K. Ellwood, and M. Carey. 1995. A general mechanism for transcriptional synergy by eukaryotic activators. Nature 377: 254-257.

Cooper, J.P., S.Y. Roth, and R.T. Simpson. 1994. The global transcription regulators, SSN6 and TUP1, play distinct roles in the establishment of a repressive chromatin structure. Genes \& Dev. 8: 1400-1410.

Driever, W., G. Thoma, and C. Nüsslein-Volhard. 1989. Determination of spatial domains of zygotic gene expression in the Drosophila embryo by the affinity of binding sites for the bicoid morphogen. Nature 340: 363-367.

Drouin, J., Y.L. Sun, M. Chamberland, V. Gauthier, A. De Lean, M. Nemer, and T.J. Schmidt. 1993. Novel glucocorticoid receptor complex with DNA element of the hormone-repressed POMC gene. EMBO /. 12: 145-156.

Fondell, J.D., A.L. Roy, and R.G. Roeder. 1993. Unliganded thyroid hormone receptor inhibits formation of a functional preinitiation complex: Implications for active repression. Genes \& Dev. 7: 1400-1410.
Gaul, U. and H. Jackle. 1987. Pole region-dependent repression of the Drosophila gap gene Krüppel by maternal gene products. Cell 51: 549-555.

Genetta, T., D. Ruezinsky, and T. Kadesch. 1994. Displacement of an E-box-binding repressor by basic helix-loop-helix proteins: Implications for B-cell specificity of the immunoglobulin heavy-chain enhancer. Mol. Cell. Biol. 14: 6153-6163.

Gerwin, N., A. LaRosee, F. Sauer, H.P. Halbritter, M. Neumann, H. Jackle, and U. Nauber. 1994. Functional and conserved domains of the Drosophila transcription factor encoded by the segmentation gene knirps. Mol. Cell. Biol. 14: 78997908.

Goodrich, J.A. and R. Tjian. 1994. TBP-TAF complexes: Selectivity factors for eukaryotic transcription. Curr. Opin. Cell Biol. 6: 403-409.

Gray, S., P. Szymanski, and M. Levine. 1994. Short-range repression permits multiple enhancers to function autonomously within a complex promoter. Genes \& Dev. 8: 1829-1838.

Han, K. and J.L. Manley. 1993a. Transcriptional repression by the Drosophila even-skipped protein: Definition of a minimal repression domain. Genes \& Dev. 7: 491-503.

- 1993b. Functional domains of the Drosophila engrailed protein. EMBO J. 12: 2723-2733.

Herschbach, B.M., M.B. Arnaud, and A.D. Johnson. 1994. Transcriptional repression directed by the yeast $\alpha 2$ protein in vitro. Nature 370: 309-311.

Hoch, M., N. Gerwin, H. Taubert, and H. Jackle. 1992. Competition for overlapping sites in the regulatory region of the Drosophila gene Krüppel. Science 256: 94-97.

Huang, J.D., D.H. Schwyter, J.M. Shirokawa, and A.J. Courey. 1993. The interplay between multiple enhancer and silencer elements defines the pattern of decapentaplegic expression. Genes \& Dev. 7: 694-704.

Ip. Y.T., R. Kraut, M. Levine, and C.A. Rushlow. 1991. The dorsal morphogen is a sequence-specific DNA-binding protein that interacts with a long-range repression element in Drosophila. Cell 64: 439-446.

Ip, Y.T., R.E. Park, D. Kosman, K. Yazdanbakhsh, and M. Levine. 1992a. dorsal-twist interactions establish snail expression in the presumptive mesoderm of the Drosophila embryo. Genes \& Dev. 6: 1518-1530.

Ip, Y.T., R.E. Park, D. Kosman, E. Bier, and M. Levine. 1992 b. The dorsal gradient morphogen regulates stripes of rhomboid expression in the presumptive neuroectoderm of the Drosophila embryo. Genes \& Dev. 6: 1728-1739.

Ip, Y.T., K. Maggert, and M. Levine. 1994. Uncoupling gastrulation and mesoderm differentiation in the Drosophila embryo. EMBO I. 13: 5826-1534.

Jaynes, J.B. and P.H. O'Farrell. 1991. Active repression of transcription by the engrailed homeodomain protein. EMBO $\mathrm{I}$. 10: $1427-1433$.

Jiang, J. and M. Levine. 1993. Binding affinities and cooperative interactions with bHLH activators delimit threshold responses to the dorsal gradient morphogen. Cell 5: 741-752.

Jiang, J., H. Cai, Q. Zhou, and M. Levine. 1993. Conversion of a dorsal-dependent silencer into an enhancer: evidence for dorsal corepressors. EMBO J. 12: 3201-3209.

Jiang, J., D. Kosman, Y.T. Ip, and M. Levine. 1991. The dorsal morphogen gradient regulates the mesoderm determinant twist in early Drosophila embryos. Genes \& Dev. 5: 18811891.

Johnson, A.D. 1995. The price of repression. Cell 81: 655-658.

Keleher, C.A., M.J. Redd, J. Schultz, M. Carlson, and A.D. Johnson. 1992. Ssn6-Tupl is a general repressor of transcription in yeast. Cell 68: 709-719.

Kirov, N., L. Zhelnin, J. Shah, and C.A. Rushlow. 1993. Con- 
version of a silencer into an enhancer: Evidence for a corepressor in dorsal-mediated repression in Drosophila. EMBO J. 12: 3193-3199.

Kosman, D., Y.T. Ip, M. Levine, and K. Arora. 1991. Establishment of the mesoderm-neuroectoderm boundary in the Drosophila embryo. Science 254: 118-122.

Lehming, N., D. Thanos, J.M. Brickman, J. Ma, T. Maniatis, and M. Ptashne. 1994. An HMG-like protein that can switch a transcriptional activator to a repressor. Nature 371: 175179.

Leptin, M. 1991. twist and snail as positive and negative regulators during Drosophila mesoderm development. Genes \& Dev. 5: 1568-1576.

Levine, M. and J.L. Manley. 1989. Transcriptional repression of eukaryotic promoters. Cell 59: 405-408.

Liao, S.M., J. Zhang, D.A. Jeffery, A.J. Koleske, C.M. Thompson, D.M. Chao, M. Viljoen, H.J. van Vuuren, and R.A. Young. 1995. A kinase-cyclin pair in the RNA polymerase II holoenzyme. Nature 374: 193-196.

Licht, J.D., M. Ro, M.A. English, M. Grossel, and U. Hansen. 1993. Selective repression of transcriptional activators at a distance by the Drosophila Kruppel protein. Proc. Natl. Acad. Sci. 90: 11361-11365.

Licht, J.D., W. Hanna-Rose, J.C. Reddy, M.A. English, M. Ro, M. Grossel, R. Shaknovich, and U. Hansen. 1994. Mapping and mutagenesis of the amino-terminal transcription repression domain of the Drosophila Kruppel protein. Mol. Cell. Biol. 14: 4057-4066.

Mauhin, V., Y. Lutz, C. Dennefeld, and A. Alberga. 1993. Definition of the DNA-binding site repertoire for the Drosophila transcription factor snail. Nucleic Acids Res. 21: 3951-3957.

Pan, D., J.D. Huang, and A.J. Courey. 1991. Functional analysis of the Drosophila twist promoter reveals a dorsal-binding ventral activator region. Genes \& Dev. 5: 1892-1901.

Pankratz, M.J. and H. Jäckle. 1990. Making stripes in the Drosophila embryo. Trends Genet. 6: 287-292.

Paro, R. 1993. Mechanisms of heritable gene repression during development of Drosophila. Curr. Opin. Cell Biol. 5: 9991005.

Paroush, Z., R.L. Finley Jr., T. Kidd, S.M. Wainwright, P.W. Ingham, R. Brent, and D. Ish-Horowicz. 1994. groucho is required for Drosophila neurogenesis, segmentation, and sex determination and interacts directly with hairy-related bHLH proteins. Cell 79: 805-815.

Pearce, D. and K.R. Yamamoto. 1993. Mineralocorticoid and glucocorticoid receptor activities distinguished by nonreceptor factors at a composite response element. Science 259: 1161-1165.

Qian, S., M. Capovilla, and V. Pirrotta. 1991. The bx region enhancer, a distant cis-control element of the Drosophila $U b x$ gene and its regulation by hunchback and other segmentation genes. EMBO J. 10: 1415-1425.

Sauer, F., J.D. Fondell, Y. Ohkuma, R.G. Roeder, and H. Jackle. 1995. Control of transcription by Kruppel through interactions with TFIIB and TFIIE $\beta$. Nature 375: 162-164.

Sawada, S., J.D. Scarborough, N. Killeen, and D.R. Littman. 1994. A lineage-specific transcriptional silencer regulates CD4 gene expression during $\mathrm{T}$ lymphocyte development. Cell 77: 917-929.

Shimell, M.J., J. Simon, W. Bender, and M.B. O'Connor. 1994. Enhancer point mutation results in a homeotic transformation in Drosophila. Science 264: 968-971.

Simpson-Brose, M., J. Treisman, and C. Desplan. 1994. Synergy between the hunchback and bicoid morphogens is required for anterior patterning in Drosophila. Cell 78: 855-865.
Siu, G., A.L. Wurster, D.D. Duncan, T.M. Soliman, and S.M. Hedrick. 1994. A transcriptional silencer controls the developmental expression of the CD4 gene. EMBO I. 13: 3570 3579.

Small, S. and M. Levine. 1991. The initiation of pair-rule stripes in the Drosophila blastoderm. Curr. Opin. Genet. Dev. 1: 255-260.

Small, S., R. Kraut, T. Hoey, R. Warrior, and M. Levine. 1991. Transcriptional regulation of a pair-rule stripe in Drosophila. Genes \& Dev. 5: 827-839.

Small, S., A. Blair, and M. Levine. 1992. Regulation of evenskipped stripe 2 in the Drosophila embryo. EMBO $J$. 11: 4047-4057.

Small, S., D.N. Arnosti, and M. Levine. 1993. Spacing ensures autonomous expression of different stripe enhancers in the even-skipped promoter. Development 119: 767-772.

Small, S. A. Blair, and M. Levine. 1996. Regulation of two pairrule stripes by a single enhancer in the Drosophila embryo. Dev. Biol. (in press).

Spradling, A.C. and G.M. Rubin. 1982. Transposition of cloned P elements into Drosophila germline chromosome. Science 218: $341-347$.

Stanojevic, D., T. Hoey, and M. Levine. 1989. Sequence-specific DNA-binding activities of the gap proteins encoded by hunchback and Krüppel in Drosophila. Nature 341: 331335.

Stanojevic, D., S. Small, and M. Levine. 1991. Regulation of a segmentation stripe by overlapping activators and repressors in the Drosophila embryo. Science 254: 1385-1387.

Stromstedt, P.E., L. Poellinger, J.A. Gustafsson, and J. CarlstedtDuke. 1991. The glucocorticoid receptor binds to a sequence overlapping the TATA box of the human osteostalcin promoter: A potential mechanism for negative regulation. $\mathrm{Mol}$. Cell. Biol. 11: 3379-3383.

Studer, M., H. Popperl, H. Marshall, A. Kuroiwa, and R. Krumlauf. 1994. Role of a conserved retinoic acid response element in rhombomere restriction of Hoxb-1. Science 265: $1728-1732$.

Tautz, D. and C. Pfeifle. 1989. A nonradioactive in situ hybridization method for the localization of specific RNAs in Drosophila embryos reveals a translational control of the segmentation gene hunchback. Chromosoma 98: 81-85.

Thisse, C., F. Perrin-Schmitt, C. Stoetzel, and B. Thisse. 1991. Sequence-specific transactivation of the Drosophila twist gene by the dorsal gene product. Cell 65: 1191-1201.

Treisman, J. and C. Desplan. 1989. The products of the Drosophila gap genes hunchback and Krüppel bind to the hunchback promoters. Nature 341: 335-357.

Um, M., C. Li, and J.L. Manley. 1995. The transcriptional repressor even-skipped interacts directly with TATA-binding protein. Mol. Cell. Biol. 15: 5007-5016.

Vershon, A.K. and A.D. Johnson. 1993. A short, disordered protein region mediates interactions between the homeodomain of the yeast $\alpha 2$ protein and the MCM1 protein. Cell 72: 105-112.

Wharton, K.A. Jr. and S.T. Crews. 1993. CNS midline enhancers of the Drosophila slit and Toll genes. Mech. Dev. 40: 141154.

Zhang, C.C., J. Muller, M. Hoch, H. Jackle, and M. Bienz. 1991. Target sequences for hunchback in a control region conferring Ultrabithorax expression boundaries. Development 113: 1171-1179.

Zuo, P., D. Stanojevic, J. Colgan, K. Han, M. Levine, and J. L. Manley. 1991. Activation and repression of transcription by the gap proteins hunchback and Krüppel in cultured Drosophila cells. Genes \& Dev. 5: 254-264. 


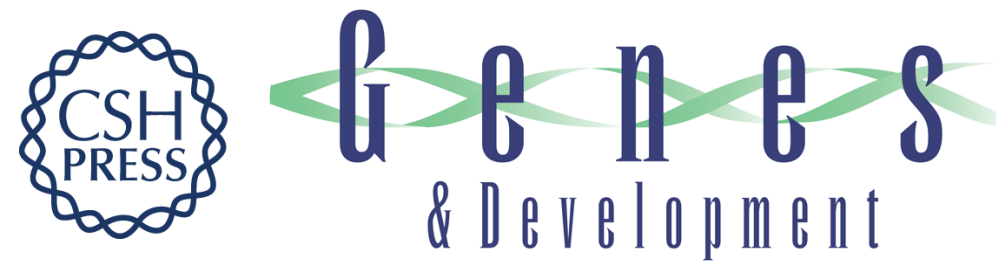

\section{Short-range transcriptional repressors mediate both quenching and direct repression within complex loci in Drosophila.}

$S$ Gray and M Levine

Genes Dev. 1996, 10:

Access the most recent version at doi:10.1101/gad.10.6.700

References This article cites 69 articles, 29 of which can be accessed free at: http://genesdev.cshlp.org/content/10/6/700.full.html\#ref-list-1

License

Email Alerting

Service

Receive free email alerts when new articles cite this article - sign up in the box at the top right corner of the article or click here.

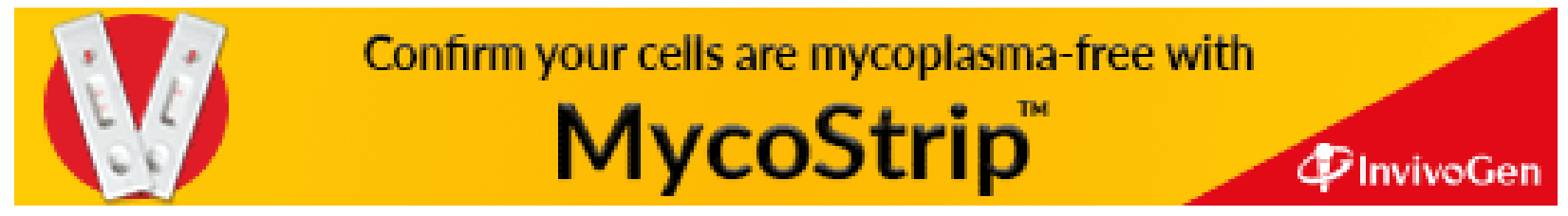

